\title{
農薬の急性毒性に及ぼす防カビ剤及び防虫剤の影響*1
}

(昭和 57 年 9 月 20 日受理)

$\begin{array}{ccc}\text { 一色賢司*2 } & \text { 宮田一正*3 } & \text { 松井重樹*3 } \\ & \text { 堤 将 和*3 } & \text { 渡辺忠雄 }\end{array}$

\section{Effects of Post-harvest Fungicides and Piperonyl Butoxide on the Acute Toxicity of Pesticides in Mice}

\author{
(Safety Evaluation for Intake of Food Additives. III)
}

\author{
Kenji Isshiki*2, Kazumasa Mryata*3, Shigeki Matsui*3, \\ Masakazu TSUTSUMI*3 and Tadao WATANABE*3 \\ ${ }^{* 2}$ The Kitakyushu Municipal Institute of Environmental Health Sciences: Shin'ike-1-2-1, \\ Tobata-ku, Kitakyushu, Japan; ${ }^{* 3}$ Department of Food Science \& Technology, Kyushu \\ University, Hakozaki, Higashi-ku, Fukuoka, Japan)
}

\begin{abstract}
Diphenyl, $o$-phenylphenol, piperonyl butoxide and thiabendazole were given to mice to confirm the potential ability of these compounds to modify the toxicity of other compounds. The acute oral toxicity $\left(\mathrm{LD}_{50}\right)$ values of equitoxic combinations of these food additives with pesticides as model toxicants were determined with male mice. The expected $\mathrm{LD}_{50}$ of a mixture was calculated from Finney's equation, and compared with the observed $\mathrm{LD}_{50}$. The pesticides studied included BPMC, carbaryl, DDVP, diazinon, EPN, fenitrothion, malathion, nicotine, parathion, parathion-methyl and pyrethrins. All the above food additives increased the toxicity of BPMC, carbaryl, diazinon, EPN and para. thion on the one hand, but decreased that of DDVP, fenitrothion, malathion and parathion-methyl on the other.
\end{abstract}

(Received September 20, 1982)

Key words: 農薬 pesticides; 急性毒性 acute toxicity; オルトフェニルフェノール o-phenylphenol; ジフェニル diphenyl; チアベンダゾール thiabendazole; ピペロニルブトキサイド piperonyl butoxide; マウス mouse

\section{緒言}

著者らは前報に抢いて, 食品添加物として使用されて いる防カビ剤や防虫剤によってマウスの薬物代謝酵素系 に変動が生じることを指摘した ${ }^{1)}$. 薬物代謝系は種々の 化合物の代謝を行って括り，特に生体に取り达まれた異 物 (xenobiotics) を極性化する代謝は生体の恒常性を保 つ重要な代謝の一つであると考えられる ${ }^{2)}$. この代謝系

*1 食品添加物の攝取に関する研究 (第 3 報)

*2 北九州市環境衛生研究所：北九州市戸畑区新池 12-1

*3 九州大学農学部食糧化学工学科: 福岡市東区箱崎 6-10-1
に変動が生じた場合には, ある種の毒物の示す毒性は変 化することが予想される ${ }^{3)}$. 農薬のなかにも毒性が変化 する可能性を有するものが存在すると考学られる そこ で, 本実験では有機リン剂, カルバメート剤及びピレト リンなどの農薬の毒性が, 防カビ剂及び防虫剤によって どのように変化するのかをマウスを用いて観察した。そ してこれらの食品添加物の供試農薬の毒性に及ぼす影響 について若干の知見を得たのでここに報告する.

実験

1. 試料

1）食品添加物

ジフェニル, オルトフェニルフェノール, ピペロニル 
ブトキサイド，チアベンダゾール：前報と同じものを使 用した

\section{2) 農薬}

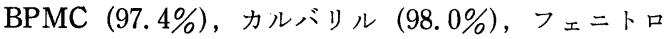
チオン $(98.5 \%)$, マラチオン $(96.0 \%)$, メチルパラチ オン $(96.0 \%)$ ，ピレトリン $(20.0 \%)$ : 三笠化学工業 (株) 製.

DDVP (98.0\%)， ダイアジノン $(90.0 \%), \quad \mathrm{EPN}$ $(90.0 \%)$ : サンケイ化学 (株) 製.

パラチオン $(97.8 \%)$ ：九州三共(株)製.

ニコチン $(96.0 \%)$ : 和光純薬工業 (株) 製.

\section{2. 毒性試験}

ddY 系雄マウスを九動 (株)より 3 週令で購入し水及 び飼料（日本クレア (株) 製, CE-2）を自由に摂取させ 7 日間馴育し，4週令体重 $19 \sim 25 \mathrm{~g}$ の時点に打いて実験 に供した．試料はすべてューンオイルに溶解，又は懸濁 させ胃ゾンデを用いてマウスに投与した，投与容量は体 重 $20 \mathrm{~g}$ 当たり $0.2 \mathrm{ml}$ とした. 対照区のマウスにはコ ーンオイルのみを投与した．投与後，水及び飼料を自由 に摂取させて 7 日間観察を続けた。本試験に先だって 1 群 3 匹のマウスを 5〜8 群用いて予試験を行った. 死亡
率 $1 / 3$ 及び $2 / 3$ となった投与量の平均值を中心として 本試験の試料の投与量を設定し， 1 群 5 匹のマウス 5 〜 8 群に投与した. 混合物の同時投与実験では Keplinger らの方法 ${ }^{4)} に$ 従って，それぞれの試料について得られた $\mathrm{LD}_{50}$ を基にして等毒性比 (equitoxic ratio) ${ }^{5)}$ になるよ らに試料を混合して投与した。すなわち試料 A，B の $\mathrm{LD}_{50}$ を $\mathrm{LD}_{50}(\mathrm{~A})$ 及び $\mathrm{LD}_{50}(\mathrm{~B})$ とすると，混合物は $\mathrm{LD}_{50}(\mathrm{~A}): \mathrm{LD}_{50}(\mathrm{~B})$ の比にA 及び $\mathrm{B}$ を混ぜ合せて調製し た. この混合物についての $\mathrm{LD}_{50}$ の期待值 $\mathrm{LD}_{50}(\mathrm{~A}, \mathrm{~B})$ は，下記の Finney の理論式 (1) より算出した ${ }^{6)} \cdot f_{\mathrm{A}}$, $f_{\mathrm{B}}$ は, 混合物中の試料 $\mathrm{A}, \mathrm{B}$ の含有率である.

$$
\frac{1}{\mathrm{LD}_{50}(\mathrm{~A}, \mathrm{~B})}=\frac{f_{\mathrm{A}}}{\mathrm{LD}_{50}(\mathrm{~A})}+\frac{f_{\mathrm{B}}}{\mathrm{LD}_{50}(\mathrm{~B})}
$$

$\mathrm{LD}_{50}$ の実測值は, Litchfield-Wilcoxon 法7)に従って推 定した.

\section{結果及び考察}

防カビ剤及び防虫剤単独のマウスへの経口投与による 毒性試験を行ったところ, Table 1 に示寸結果が得られ た. ジフェニル又はオルトフェニルフェノールを投与さ れたマウスは，しだいに動きが少なくなり下痢症状を呈 する例も見られた。死亡例は 2 日目までにすべて観察さ

Table 1. Survival of Male Mice Administered Orally with Some Food Additives ${ }^{\mathrm{a})}$

\begin{tabular}{|c|c|c|c|c|c|c|c|}
\hline \multirow{2}{*}{ Food additive } & \multirow{2}{*}{$\begin{array}{c}\text { Dose } \\
(\mathrm{mg} / \mathrm{kg})\end{array}$} & \multicolumn{4}{|c|}{ Survival days } & \multirow{2}{*}{$\begin{array}{l}\text { Death } \\
\left.\text { rate }^{b}\right)\end{array}$} & \multirow{2}{*}{$\begin{array}{c}\mathrm{LD}_{50} \\
(\mathrm{mg} / \mathrm{kg})^{\mathrm{c})}\end{array}$} \\
\hline & & 1 & 2 & 34 & $>7$ & & \\
\hline \multirow{5}{*}{ Diphenyl } & 1250 & & & & 5 & $0 / 5$ & 1900 \\
\hline & 1540 & & 1 & & 4 & $1 / 5$ & $(1600-2200)^{d)}$ \\
\hline & 1890 & 3 & & & 2 & $3 / 5$ & \\
\hline & 2330 & 1 & 3 & & 1 & $4 / 5$ & \\
\hline & 3520 & 3 & 2 & & & $5 / 5$ & \\
\hline \multirow{5}{*}{ o-Phenylphenol } & 2120 & & & & 5 & $0 / 5$ & 3100 \\
\hline & 2600 & 1 & & & 4 & $1 / 5$ & $(2700-3600)$ \\
\hline & 3200 & 2 & 1 & & 2 & $3 / 5$ & \\
\hline & 3940 & 3 & 1 & & 1 & $4 / 5$ & \\
\hline & 4840 & 3 & 2 & & 0 & $5 / 5$ & \\
\hline \multirow[t]{5}{*}{ Piperony butoxide } & 1760 & & & & 5 & $0 / 5$ & 2600 \\
\hline & 2170 & 1 & & & 4 & $1 / 5$ & $(2300-3000)$ \\
\hline & 2670 & 1 & 1 & 1 & 2 & $3 / 5$ & \\
\hline & 3280 & 3 & 1 & & 1 & $4 / 5$ & \\
\hline & 4030 & 4 & & 1 & 0 & $5 / 5$ & \\
\hline \multirow[t]{6}{*}{ Thiabendazole } & 1000 & & & & 5 & $0 / 5$ & 1600 \\
\hline & 1230 & 1 & & & 4 & $1 / 5$ & $(1300-2000)$ \\
\hline & 1500 & & 1 & 1 & 3 & $2 / 5$ & \\
\hline & 1850 & & 3 & 1 & 2 & $3 / 5$ & \\
\hline & 2280 & 1 & 3 & & 1 & $4 / 5$ & \\
\hline & 2800 & & 4 & 1 & 0 & $5 / 5$ & \\
\hline
\end{tabular}

a) Four-weeks old ddY mice (19-25 g) were used.

b) Number of dead/number of treated

c) Values were evaluated with Litchfield-Wilcoxon method.

d) Confidence limit $(95 \%)$ 
れ，その後に死亡するマウスはなかった. ジフェニルの $\mathrm{LD}_{50}$ 值は $1900 \mathrm{mg} / \mathrm{kg}$ であった. また, オルトフェニ ルフェノールの $\mathrm{LD}_{50}$ 值は $3100 \mathrm{mg} / \mathrm{kg}$ であった. ピペ ロニルブトキサイドを投与したマウスは, 数分後にはう ずくまり，時折振せんを起こし毛並が乱れていった．高 濃度投与区では眼や鼻の充血や黒色の軟便の排泄が観察 された. 多くの死亡例は投与後 24 時間以内に見られた が， 2 又は 3 日目に死亡した例もあった．ピペロニルブ トキサイドの $\mathrm{LD}_{50}$ 值は, $2600 \mathrm{mg} / \mathrm{kg}$ であった. チア ベンダゾールを投与されたマウスは, 初めはケージ中を 動き回り振せん, 立毛を呈する例む見られたが, その後 ほとんど動かなくなった. チアベンダジールの $\mathrm{LD}_{50}$ 值 は, $1600 \mathrm{mg} / \mathrm{kg}$ であった.

前報1 で述べたように, ジフェニル，オルトフェニル フェノール，ピペロニルブトキサイド及びチアベンダゾ
一ルは薬物代謝系に変化を与えると考えられた。これら の食品添加物もそれぞれ薬物代謝系によって代謝される ことから ${ }^{8) \sim 10)}$, 同時に摂取された場合には毒性に変化が 生じる可能性があると考えられた。 そこまでまず Finney の理論式 (1) ${ }^{6)}$ より種々に組み合せた混合物につい ての $\mathrm{LD}_{50}$ の期待值を算出した。 そして, 実際に各食品 添加物を等毒性比に混合しマウスに投与して $\mathrm{LD}_{50}$ 值を 測定した. 混合物についての $\mathrm{LD}_{50}$ の期待値, 実測値及 び両者の比は Table 2 のと拈りであった. 両者の值に 大きな差は観察されず, 両者の比は $0.66 〜 1.11$ の範囲 にあり，1よりる小さな比を示するのが多かった．従っ て，これらの食品添加物の混合物の毒性は相乗的といら よりも相加的あるいは毒性が弱くなる傾向にあることが 判明した.

次に，防カビ剤及び防虫剤のもつ薬物代謝への影響力

Table 2. Expected and Observed $\mathrm{LD}_{50}$ of Combinations of Food Additives in Mice ${ }^{\mathrm{a})}$

\begin{tabular}{|c|c|c|c|}
\hline Combination & $\begin{array}{l}\left.\text { Expected } \mathrm{LD}_{50} \mathrm{~b}\right) \\
(\mathrm{mg} / \mathrm{kg})\end{array}$ & $\begin{array}{c}\text { Observed } \mathrm{LD}_{50}{ }^{\mathrm{c})} \\
(\mathrm{mg} / \mathrm{kg})\end{array}$ & $\begin{array}{c}\text { Ratio }^{\mathrm{d})} \\
\mathrm{E} / \mathrm{O}\end{array}$ \\
\hline $\begin{array}{l}\text { Diphenyl } \\
\quad+o \text {-phenylphenol }\end{array}$ & 2500 & 2800 & 0.89 \\
\hline $\begin{array}{l}\text { Diphenyl } \\
\quad+\text { piperonyl butoxide }\end{array}$ & 2300 & 3500 & 0.66 \\
\hline $\begin{array}{l}\text { Diphenyl } \\
\quad+\text { thiabendazole }\end{array}$ & 1800 & 1900 & 0.95 \\
\hline $\begin{array}{l}\text { o-Phenylphenol } \\
\quad \text { + piperonyl butoxide }\end{array}$ & 2900 & 3200 & 0.91 \\
\hline $\begin{array}{l}o \text {-Phenylphenol } \\
\quad+\text { thiabendazole }\end{array}$ & 2400 & 2600 & 0.92 \\
\hline $\begin{array}{l}\text { Piperonyl butoxide } \\
\text { + thiabendazole }\end{array}$ & 2100 & 2300 & 0.91 \\
\hline $\begin{array}{l}\text { Diphenyl } \\
\quad+o \text {-phenylphenol } \\
\quad+\text { piperonyl butoxide }\end{array}$ & 2500 & 3400 & 0.75 \\
\hline $\begin{array}{l}\text { Diphenyl } \\
\quad+o \text {-phenylphenol } \\
\quad \text { thiabendazole }\end{array}$ & 2200 & 2900 & 0.76 \\
\hline $\begin{array}{l}\text { Diphenyl } \\
\quad \text { + piperonyl butoxide } \\
\quad \text { +thiabendazole }\end{array}$ & 2000 & 1800 & 1.11 \\
\hline $\begin{array}{l}\text { o-Phenylphenol } \\
\quad+\text { piperonyl butoxide } \\
\quad+\text { thiabendazole }\end{array}$ & 2400 & 3200 & 0.75 \\
\hline $\begin{array}{l}\text { Diphenyl } \\
\quad+o \text {-phenylphenol } \\
\quad \text { + piperonyl butoxide } \\
\text { +thiabendazole }\end{array}$ & 2300 & 2100 & 1.10 \\
\hline
\end{tabular}

a) Food additives were mixed at the equitoxic ratio (based on the $\mathrm{LD}_{50}$ ), and the mixture was administered orally into mice (ddY, 4 weeks old, male, 19-25 g).

b) Values were calculated from Finney's equation.

c) Values were evaluated with Litchfield-Wilcoxon method.

d) The ratio of the expected $L D_{50}$ to the observed $L D_{50}$. 
Table 3. Survival of Male Mice-(ddY) Administered Orally with Pestcides ${ }^{\text {a }}$ )

\begin{tabular}{|c|c|c|c|c|c|c|c|}
\hline \multirow{2}{*}{ Pesticides } & \multirow{2}{*}{$\begin{array}{c}\text { Dose } \\
(\mathrm{mg} / \mathrm{kg})\end{array}$} & \multicolumn{4}{|c|}{ Survival day } & \multirow{2}{*}{$\begin{array}{l}\text { Death } \\
\text { rate }^{\text {b) }}\end{array}$} & \multirow{2}{*}{$\frac{\mathrm{LD}_{50}}{\left.(\mathrm{mg} / \mathrm{kg})^{\mathrm{c}}\right)}$} \\
\hline & & $1 / 24$ & $1 / 8$ & 1 & $2>7$ & & \\
\hline \multirow[t]{5}{*}{ BPMC } & 120 & & & & 5 & $0 / 5$ & 200 \\
\hline & 145 & & 1 & & 4 & $1 / 5$ & $(154-260)^{\text {d) }}$ \\
\hline & 180 & 2 & & & 3 & $2 / 5$ & - \\
\hline & 220 & 3 & & & 2 & $3 / 5$ & \\
\hline & 272 & 2 & 2 & & 1 & $4 / 5$ & \\
\hline \multirow{6}{*}{ Carbaryl } & 160 & & & & 5 & $0 / 5$ & 220 \\
\hline & 185 & & & 1 & 4 & $1 / 5$ & $(190-240)$ \\
\hline & 200 & & 2 & & 3 & $2 / 5$ & \\
\hline & 214 & & 3 & & 2 & $3 / 5$ & \\
\hline & 268 & 3 & 1 & & 1 & $4 / 5$ & \\
\hline & 330 & 5 & & & 0 & $5 / 5$ & \\
\hline \multirow{5}{*}{ DDVP } & 83 & & & & 5 & $0 / 5$ & 140 \\
\hline & 101 & & & 1 & 4 & $1 / 5$ & $(110-190)$ \\
\hline & 124 & 2 & & & 3 & $2 / 5$ & \\
\hline & 165 & 3 & & & 2 & $3 / 5$ & \\
\hline & 186 & 5 & & & 0 & $5 / 5$ & \\
\hline \multirow{4}{*}{ Diazinon } & 14 & & & & 5 & $0 / 5$ & 17 \\
\hline & 16 & & & 2 & 3 & $2 / 5$ & $(14-20)$ \\
\hline & 18 & 1 & 2 & & 2 & $3 / 5$ & \\
\hline & 20 & 2 & 3 & & 0 & $5 / 5$ & \\
\hline \multirow[t]{5}{*}{ EPN } & 21 & & & & 5 & $0 / 5$ & 30 \\
\hline & 26 & & 1 & 1 & 3 & $2 / 5$ & $(23-37)$ \\
\hline & 32 & & 2 & 1 & 2 & $3 / 5$ & \\
\hline & 39 & & 2 & 2 & 1 & $4 / 5$ & \\
\hline & 48 & 1 & 4 & & 0 & $5 / 5$ & \\
\hline \multirow[t]{5}{*}{ Fenitrothion } & 700 & & & & 5 & $0 / 5$ & 1300 \\
\hline & 900 & & & 1 & 4 & $1 / 5$ & $(1050-1610)$ \\
\hline & 1200 & & 1 & 1 & 3 & $2 / 5$ & \\
\hline & 1500 & 1 & 1 & 1 & 2 & $3 / 5$ & \\
\hline & 1800 & 1 & 3 & 1 & 0 & $5 / 5$ & \\
\hline \multirow{5}{*}{ Malathion } & 700 & & & 1 & 5 & $5 / 5$ & 1100 \\
\hline & 900 & & & 1 & 4 & $1 / 5$ & $(920-1310)$ \\
\hline & 1000 & & 2 & & 3 & $2 / 5$ & \\
\hline & 1200 & & 2 & 1 & 2 & $3 / 5$ & \\
\hline & 1500 & & 3 & 2 & 0 & $5 / 5$ & \\
\hline \multirow[t]{5}{*}{ Nicotine } & 76 & & & 1 & 4 & $1 / 5$ & 100 \\
\hline & 94 & 1 & 1 & & 3 & $2 / 5$ & $(80-124)$ \\
\hline & 112 & 3 & & & 2 & $3 / 5$ & \\
\hline & 130 & 4 & & & 1 & $4 / 5$ & \\
\hline & 150 & 5 & & & 0 & $5 / 5$ & \\
\hline \multirow{4}{*}{ Parathion } & 6 & i & & & 5 & $0 / 5$ & 8.0 \\
\hline & 7 & 1 & 1 & & 3 & $2 / 5$ & $(6.3-10)$ \\
\hline & 9 & & 3 & & 2 & $3 / 5$ & \\
\hline & 11 & 1 & 4 & & 0 & $5 / 5$ & \\
\hline \multirow[t]{4}{*}{ Parathion-methyl } & 21 & & 1 & & 4 & $1 / 5$ & 30 \\
\hline & 27 & 1 & 1 & & 3 & $2 / 5$ & $(24-38)$ \\
\hline & 33 & 2 & 1 & & 2 & $3 / 5$ & \\
\hline & 42 & 1 & 2 & 1 & 1 & $4 / 5$ & \\
\hline \multirow[t]{5}{*}{ Pyrethrins } & 350 & & & & 5 & $0 / 5$ & 520 \\
\hline & 460 & & 2 & & 3 & $2 / 5$ & $(380-710)$ \\
\hline & 590 & & 2 & 1 & 2 & $3 / 5$ & \\
\hline & 770 & & 2 & 2 & 1 & $4 / 5$ & \\
\hline & 1000 & & 2 & 3 & 0 & $5 / 5$ & \\
\hline
\end{tabular}

a) Four-weeks old mice (19-25 g) were used.

b) Number of dead/number of treated.

c) Confidence limit (95\%). 
Table 4. Expected and Observed Oral $\mathrm{LD}_{50}$ of Combinations of Diphenyl and Pesticides in Mice $^{a}$

\begin{tabular}{|c|c|c|c|}
\hline Combination & $\begin{array}{l}\text { Expected } \mathrm{LD}_{50} \\
(\mathrm{mg} / \mathrm{kg})^{\mathrm{b})}\end{array}$ & $\begin{array}{l}\text { Observed } \mathrm{LD}_{50} \\
(\mathrm{mg} / \mathrm{kg})^{\mathrm{c})}\end{array}$ & $\begin{array}{l}\text { Ratio } \\
\mathrm{E} / \mathrm{O}^{\mathrm{d})}\end{array}$ \\
\hline $\begin{array}{l}\text { Diphenyl } \\
\text { +BPMC }\end{array}$ & 1050 & 600 & 1.75 \\
\hline $\begin{array}{l}\text { Diphenyl } \\
\quad+\text { carbaryl }\end{array}$ & 1060 & 540 & 1.96 \\
\hline $\begin{array}{l}\text { Diphenyl } \\
\text { +DDVP }\end{array}$ & 1020 & 1620 & 0.63 \\
\hline $\begin{array}{l}\text { Diphenyl } \\
\quad+\text { diazinon }\end{array}$ & 960 & 690 & 1.40 \\
\hline $\begin{array}{l}\text { Diphenyl } \\
+ \text { EPN }\end{array}$ & 965 & 700 & 1.38 \\
\hline $\begin{array}{l}\text { Diphenyl } \\
\quad+\text { fenitrothion }\end{array}$ & 1650 & 2700 & 0.61 \\
\hline $\begin{array}{l}\text { Diphenyl } \\
\quad+\text { malathion }\end{array}$ & 1500 & 2100 & 0.71 \\
\hline $\begin{array}{l}\text { Diphenyl } \\
\text { +nicotine }\end{array}$ & 1000 & 1040 & 0.96 \\
\hline $\begin{array}{l}\text { Diphenyl } \\
\quad+\text { parathion }\end{array}$ & 954 & 700 & 1.36 \\
\hline $\begin{array}{l}\text { Diphenyl } \\
\quad+\text { papathion-methyl }\end{array}$ & 965 & 2240 & 0.43 \\
\hline $\begin{array}{l}\text { Diphenyl } \\
\quad+\text { pyrethrins }\end{array}$ & 1210 & 1350 & 0.90 \\
\hline
\end{tabular}

a) Diphenyl and pesticide were mixed at the equitoxic ratio based on the $\mathrm{LD}_{50}$, and the mixture was administered orally into mice (ddY, 4 weeks old, male, 19-25 g).

b) Values were calculated from Finney's equation.

c) Values were evaluated with Litchfield-Wilcoxon method.

c) The ratio of the expected $L D_{50}$ to the observed $L D_{50}$.

Table 5. Expected and Observed Oral $\mathrm{LD}_{50}$ of Combinations of $o$-Phenylphenol and Pesticides in Mice $^{\mathrm{a})}$

\begin{tabular}{|c|c|c|c|}
\hline Combination & $\underset{(\mathrm{mg} / \mathrm{kg})^{\mathrm{b})}}{\text { Expected } \mathrm{LD}_{50}}$ & $\begin{array}{l}\text { Observed LD } D_{50} \\
(\mathrm{mg} / \mathrm{kg})^{\mathrm{c})}\end{array}$ & $\begin{array}{l}\text { Ratio } \\
\mathrm{E} / \mathrm{O}^{\mathbf{d})}\end{array}$ \\
\hline$o$-Phenylphenol & 1650 & 1030 & 1.60 \\
\hline $\begin{array}{l}o \text {-Phenylphenol } \\
\text { + carbaryl }\end{array}$ & 1660 & 800 & 2.10 \\
\hline $\begin{array}{l}o \text {-Phenylphenol } \\
\quad+\text { DDVP }\end{array}$ & 1620 & 3520 & 0.46 \\
\hline $\begin{array}{l}o \text {-Phenylphenol } \\
+ \text { diazinon }\end{array}$ & 1560 & 1130 & 1.39 \\
\hline $\begin{array}{l}o \text {-Phenylphenol } \\
\text { +EPN }\end{array}$ & 1565 & 1250 & 1.25 \\
\hline $\begin{array}{l}o \text {-Phenylphenol } \\
\quad+\text { fenitrothion }\end{array}$ & 2250 & 3700 & 0.61 \\
\hline $\begin{array}{c}o \text {-Phenylphenol } \\
+ \text { malathion }\end{array}$ & 2100 & 4300 & 0.49 \\
\hline $\begin{array}{l}o \text {-Phenylphenol } \\
\text { + nicotine }\end{array}$ & 1600 & 1580 & 1.01 \\
\hline $\begin{array}{l}o \text {-Phenylphenol } \\
\text { + parathion }\end{array}$ & 1554 & 1300 & 1.20 \\
\hline$o$-Phenylphenol & 1565 & 3630 & 0.43 \\
\hline $\begin{array}{l}\text { + parathion-methyl } \\
\text { o-Phenylphenol } \\
\text { +pyrethrins }\end{array}$ & 1810 & 2000 & 0.91 \\
\hline
\end{tabular}

a) $o$-Phenylphenol and pesticide were mixed at the equitoxic ratio based on the $\mathrm{LD}_{50}$, and the mixture was administered orally into mice (ddY, 4 weeks old, male, 19-25 g).

b) Values were calculated from Finney's equation.

c) Values were evaluated with Litchfield-Wilcoxon method.

d) The ratio of the expected $L D_{50}$ to the observed $L D_{50}$. 
Table 6. Expected and Observed Oral $\mathrm{LD}_{50}$ of Combinations of Piperonyl Butoxide and Pesticides in Mice $^{\text {a) }}$

\begin{tabular}{|c|c|c|c|}
\hline Combination & $\begin{array}{l}\text { Expected } \mathrm{LD}_{50} \\
(\mathrm{mg} / \mathrm{kg})^{\mathrm{b})}\end{array}$ & $\begin{array}{l}\text { Observed } \mathrm{LD}_{50} \\
(\mathrm{mg} / \mathrm{kg})^{\mathrm{c})}\end{array}$ & $\begin{array}{l}\text { Ratio } \\
\mathrm{E} / \mathrm{O}^{\mathbf{d})}\end{array}$ \\
\hline $\begin{array}{l}\text { Piperonyl butoxide } \\
+ \text { BPMC }\end{array}$ & 1400 & 550 & 2.55 \\
\hline $\begin{array}{l}\text { Piperonyl butoxide } \\
\text { + carbaryl }\end{array}$ & 1410 & 560 & 2.52 \\
\hline $\begin{array}{l}\text { Piperonyl butoxide } \\
\text { +DDVP }\end{array}$ & 1370 & 3200 & 0.43 \\
\hline $\begin{array}{l}\text { Piperonyl butoxide } \\
+ \text { diazinon }\end{array}$ & 1310 & 1040 & 1.26 \\
\hline $\begin{array}{l}\text { Piperonyl butoxide } \\
+ \text { EPN }\end{array}$ & 1315 & 480 & 2.74 \\
\hline $\begin{array}{l}\text { Piperonyl butoxide } \\
+ \text { fenitrothion }\end{array}$ & 1950 & 3300 & 0.60 \\
\hline $\begin{array}{l}\text { Piperonyl butoxide } \\
+ \text { malathion }\end{array}$ & 1850 & 3850 & 0.48 \\
\hline $\begin{array}{l}\text { Piperonyl butoxide } \\
+ \text { nicotine }\end{array}$ & 1350 & 1620 & 0.83 \\
\hline $\begin{array}{l}\text { Piperonyl butoxide } \\
+ \text { parathion }\end{array}$ & 1304 & 780 & 1.67 \\
\hline $\begin{array}{l}\text { Piperonyl butoxide } \\
\text { + parathion-methyl }\end{array}$ & 1315 & 3460 & 0.38 \\
\hline $\begin{array}{l}\text { Piperonyl butoxide } \\
\text { + pyrethrins }\end{array}$ & 1560 & 1150 & 1.36 \\
\hline
\end{tabular}

a) Piperonyl butoxide and pesticide were mixed at the equitoxic ratio based on the $\mathrm{LD}_{50}$, and the mixture was administered orally into mice (ddY, 4 weeks old, male, 19-25 g).

b) Values were calculated from Finney's equation.

c) Values were evaluated with Litchfield-Wilcoxon method.

d) The ratio of the expected $L_{50}$ to the observed $L_{50}$.

Table 7. Expected and Observed Oral $\mathrm{LD}_{50}$ of Combination of Thiabendazole and Pesticides in Mice $\left.^{a}\right)$

\begin{tabular}{|c|c|c|c|}
\hline Combination & $\underset{(\mathrm{mg} / \mathrm{kg})^{\mathrm{b})}}{\operatorname{Expected~} \mathrm{LD}_{50}}$ & $\begin{array}{l}\text { Observed } \mathrm{LD}_{50} \\
(\mathrm{mg} / \mathrm{kg})^{\mathrm{c})}\end{array}$ & $\begin{array}{l}\text { Ratio } \\
\mathrm{E} / \mathrm{O}^{\mathrm{d})}\end{array}$ \\
\hline $\begin{array}{l}\text { Thiabendazole } \\
\text { +BPMC }\end{array}$ & 900 & 530 & 1.70 \\
\hline $\begin{array}{l}\text { Thiabendazole } \\
\text { + carbaryl }\end{array}$ & 910 & 440 & 2.10 \\
\hline $\begin{array}{l}\text { Thiabendazole } \\
\text { +DDVP }\end{array}$ & 870 & 1610 & 0.54 \\
\hline $\begin{array}{l}\text { Thiabendazole } \\
\text { +diazinon }\end{array}$ & 809 & 660 & 1.23 \\
\hline $\begin{array}{l}\text { Thiabendazole } \\
+ \text { EPN }\end{array}$ & 815 & 680 & 1.20 \\
\hline $\begin{array}{l}\text { Thiahendazole } \\
\text { + fenitrothion }\end{array}$ & 1500 & 1800 & 0.83 \\
\hline $\begin{array}{c}\text { Thiabendazole } \\
\text { +malathion }\end{array}$ & 1350 & 2400 & 0.56 \\
\hline $\begin{array}{l}\text { Thiabendazole } \\
\text { + nicotine }\end{array}$ & 850 & 1180 & 0.72 \\
\hline $\begin{array}{c}\text { Thiabendazole } \\
+ \text { parathion }\end{array}$ & 804 & 600 & 1.34 \\
\hline $\begin{array}{l}\text { Thiabendazole } \\
\quad \text { +parathion-methyl }\end{array}$ & 815 & 1540 & 0.53 \\
\hline $\begin{array}{l}\text { Thiabendazole } \\
\text { + pyrethrins }\end{array}$ & 1060 & 960 & 1.10 \\
\hline
\end{tabular}

a) Thiabendazole and pesticide were mixed at the equitoxic ratio based on the $\mathrm{LD}_{50}$, and the mixture was administered orally into mice (ddY, 4 weeks, male, 19-25 g).

b) Values were calculated from Finney's equation.

c) Values were evaluated with Litchfield-Wilcoxon method.

d) The ratio of the expected $L D_{50}$ to the observed $L D_{50}$. 
が他の化合物の毒性にも影響を与える可能性の有無を確 認するために11種の農薬をモデルとして同時投与毒性試 験を行った. まず各農薬のマウスへの単独投与実験を行 い Table 3 の結果を得た. 続いて, 各食品添加物之各農 薬とのマウスへの同時投与実験を行い Table 4 7 の結 果を得た. ジフェニルは, BPMC, カルバリル, ダイア ジノン, $\mathrm{EPN}$, パラチオンの毒性を増加させ, DDVP, フェニトロチオン, マラチオン, メチルパラチオンの毒 性を低減させた (Table 4)。また，オルトフェニルフェ ノールは, BPMC, カルバリル, ダイアジノン, EPN, パラチオンの毒性を増加させ, DDVP, フェニトロチオ ン, マラチオン, メチルパラチオンの毒性を低減させた (Table 5). ピペロニルブトキサイドは, BPMC, カルバ リル, ダイアジノン, $\mathrm{EPN}$, パラチオン, ピレトリンの 毒性を増加させ, DDVP, フェニトロチオン, マラチオ ン, ニコチン, メチルパラチオンの毒性を低減させた (Table 6). さらに, チアベンダゾールは, BPMC, カル バリル, ダイアジノン, $\mathrm{EPN}$, パラチオンの毒性を增加 させ, DDVP, フェニトロチオン, マラチオン, ニュチ ン, メチルパラチオンの毒性を低減させた (Table 7). このように農薬のなかには防カビ剤や防虫剤と混合され ることによりその毒性に変動が生じるものがあることが 明らかになった。毒性が増強される BPMC, カルバリ ル，ダイアジノン, $\mathrm{EPN}$, パラチオンなどはチトクロー ム P-450を中心とする薬物代謝䤃素系によって解毒さ れると考光られる ${ }^{11), 12)}$. そしてその代謝系が防カビ剂 や防虫剂による影響を受け解毒されにくくなるため毒性 が強くなると推定さ礼た. 一方, 毒性が弱くなるDDVP, フェニトロチオン, マラチオン, メチルパラチオンは, いずれも二つのメチル基を持つ有機りン剂であった．細 胞質に存在するグルタチオン-S-アルキルトランスフェ ラーゼの特異性は二つのメチル基を持つ有機リン剤に高 いと報告されている ${ }^{13), 14)}$. これらの有機リン郕の毒性 の低下の一因として，この酵素と薬物代謝系酵系に対す る防カビ剤や防虫剤の影響力の違いが推察された。 た, マラチオンは, 影響を受けにくいと考兄られる細胞 質のカルボキシェステラーゼによる解毒作用 ${ }^{15}$ も毒性低 下の一因であろうと思われた。

Keplinger らは, 100 種類を越觉る化合物の同時投与 毒性試験の結果を検討し, 毒性の増加又は低減作用の判 断基準に考察を加えている4). そして， $\mathrm{LD}_{50}$ の期待値 と実測值の比1.00を判断の中心（相加的）と見るよりも， 経験的に 0.90 程度の比率を中心とみなす方が良いと述べ ている. 毒性試験に拈ける用量反応曲線（投与量対死亡 率）は，原点を通る直線ではないことなどを考えると 0.90 程度の比は毒性の低減を示するのではなく, また 1.00 という比は相加的というよりる毒性がやや強くあら われる傾向があると考兄る方が妥当であるように思われ た、いずれにしても今回実験を行った農薬のなかには防
カビ剤や防虫剂との同時投与によってその毒性に変化を 生じるものがあった. そして, 防カビ剤や防虫剂の影響 を受けて毒性に変化を生じる化合物はこの他にも存在す る可能性があると考光られた。

\section{要約}

防カビ剂及び防虫剂を農薬と同時にマウスに経口的に 投与し, 急性毒性を観察し次のような結果を得た。

1) ジフェニルは, BPMC, カルバリル，ダイアジノ ン, $\mathrm{EPN}$, パラチオンの毒性を増加させた。

2) ジフェニルは, DDVP, フェニトロチオン, マラ チオン, メチルパラチオンの毒性を低下させた.

3）オルトフェニルフェノール，チアベンダゾール及 びピペロニルブトキサイドも, ジフェニルと同様に農薬 の毒性を変化させた.

なお，本研究の一部は第 5 回国際農薬化学会議 $(1982$ 年 8 月, 京都) 飞预いて発表した.

文献

1）一色賢司, 宮田一正, 松井重樹, 堤 将和, 渡辺 忠雄：食衛誌. 24, 161 165 (1983).

2) 森陽, 菅家祐輔: “食品衛生の生物科学” p. 33 42 (1982) 三共出版.

3) Franklin, M. R.: Environ. Health Perspectives 14, 29 37 (1976).

4) Keplinger, M. L., Deichman, W. B.: Toxicol. Appl. Pharmacol. 10, 586 595 (1967).

5) Smyth, H. F. Jr., Weil, C.S., West, J.S., Carpenter, C. P.: ibid. 17, 498 503 (1970).

6) Finney, D. J.: "Probit Analysis, 2nd ed." p. 131 136 (1952) Cambridge Univ. Press, Cambridge, England.

7) Litchfield, J. T. Jr., Wilcoxon, F.: J. Pharmacol. Exp. Therap. 96, 99 113 (1949).

8) Wiebkin, P., Fry, J. R., Jones, C. A., Lowing, R., Bridges, J. W.: Xenobiotica 6, 725 743 (1976).

9) Hodgson, E., Philpot, R. M.: Drug Metab. Rev. 3, 231 301 (1974).

10) Wilson, C. G., Parke, D. V., Green, J., Cawthorne, M. A.: Xenobiotica 9, 343 351 (1979).

11) Eto, M.: "Organophosphorus Pesticides: Organic and Biological Chemistry" p. 158 204 (1974) CRC Press Inc., Cleaveland, Ohio, U.S. A..

12）山下恭平, 水谷純也, 藤田稔夫, 丸茂晋吾, 江藤 守総, 高橋信考: “農薬の科学” p. 161 179 (1979) 文永堂.

13) Fukami, J., Shishido, T.: J. Econ. Entomol. 59, 1338 1346 (1966).

14) Levine, B. S., Murphy, S. D.: Toxicol. Appl. Pharmacol. 40, 393 406 (1977).

15) Matsumura, F., Ward, C. T.: Arch. Environ. Health 13, 257 269 (1966). 